\title{
Occurrence of toxic metals and their selective pressure for antibiotic-resistant clinically relevant bacteria and antibiotic-resistant genes in river receiving systems under tropical conditions
}

\author{
Dhafer Mohammed M. Al Salah ${ }^{1,2} \cdot$ Amandine Laffite $^{1} \cdot$ Periyasamy Sivalingam $^{3} \cdot$ John $^{\text {Poté }}{ }^{1}$
}

Received: 26 May 2021 / Accepted: 15 October 2021 / Published online: 5 November 2021

(c) The Author(s) 2021

\begin{abstract}
The co-occurrence of heavy metals, antibiotic-resistant bacteria (ARB) and antibiotic-resistance genes (ARGs) from hospital effluents spreading into the river receiving systems and evaluating associated risks are topics of scientific interest and still under-studied in developing countries under tropical conditions. To understand the selectors of the ARGs, we examined the occurrence of heavy metals ( $\mathrm{Cr}, \mathrm{Co}, \mathrm{Ni}, \mathrm{Cu}, \mathrm{Cd}, \mathrm{Pb}$ and $\mathrm{Zn}$ ), associated $\mathrm{ARB}$ ( $\beta$-lactam-resistant Escherichia coli, $\beta$-lactamresistant Enterobacteriaceae, and carbapenem-resistant Enterobacteriaceae) and ARGs ( $\left.b l a_{O X A}, b l a_{C T X-M}, b l a_{I M P}, b l a_{T E M}\right)$ in water and sediments from two sub-urban rivers receiving urban and hospital effluent waters in the Democratic Republic of the Congo (DRC). High abundances of ARB and ARGs were observed in all sediment samples. All the metal contents correlated negatively with grain size $(-0.94 \leq r \leq-0.54, p<0.05)$ except for Ni and positively with organic matter content and total copies of $16 \mathrm{~s}$ rRNA $(0.42 \leq r \leq 0.79, p<0.05)$, except for $\mathrm{Ni}$ and $\mathrm{Zn}$. The metals had a significant positive correlation with the faecal indicator Enterococcus except for $\mathrm{Ni}$ and $\mathrm{Cd}(0.43 \leq r \leq 0.67, p<0.05)$. Carbapenem-resistant Enterobacteriaceae correlated negatively with $\mathrm{Zn}(r=-0.44, p<0.05)$ and positively with all the rest of toxic metals $(0.58 \leq r \leq 1.0, p<0.05)$. These results suggested that some metals had a great influence on the persistence of ARB and ARGs in sediments. Overall, this study strongly recommends the managing urban wastewater to preserve water resources used for human and agricultural purposes. Additionally, we recommend the utilizing biological indicators (faecal indicator bacteria, ARB, ARGs) when investigating urban wastewater pollutions.
\end{abstract}

Keywords Heavy metals $\cdot$ Sediments $\cdot$ Urban wastewater $\cdot$ Pollution $\cdot$ Antibiotic resistance $\cdot$ Public health

\section{Introduction}

Responsible Editor: Robert Duran

John Poté

john.pote@unige.ch

1 Department F. A. Forel, Faculty of Sciences, Earth and Environmental Sciences, Institute F. A. Forel and Institute of Environmental Sciences, University of Geneva, Bd Carl-Vogt 66, CH-1211 Geneva 4, Switzerland

2 King Abdulaziz City for Science and Technology, Joint Centers of Excellence Program, Prince Turki the 1st St, Riyadh 11442, Saudi Arabia

3 Postgraduate and Research Department of Microbiology, Jamal Mohamed College, Tamil Nadu, Tiruchirappalli 620020, India
All human civilizations that sprang in the past have depended on and were structured around freshwater resources. Freshwater resources are a precious commodity and essential to human life and have been declared a human right by the United Nations General Assembly in Resolution 64/292 (Ki-moon and General 2010; Daily et al. 2012). However, the spread and dissemination of ARB and ARGs in the fresh water environment have become a global health concern and considered to be an emerging environmental pollutant (Sivalingam et al. 2020; Devarajan et al. 2016; Sanderson et al. 2016). Several factors other than antibiotics influence the spread and dissemination of ARGs in the environment (Devarajan et al. 2015). More worryingly, in developing countries, such as Sub-Saharan African 
countries, the discharge of raw sewage into rivers is common (Al Salah et al. 2020; Laffite et al. 2020, 2016). This practice deteriorates the quality of freshwater resources by contaminants of ARGs, heavy metals, antibiotics and ARB (Tripathi and Tripathi 2017, Ngweme et al. 2021). Toxic metals also adversely affect the environment and its flora which could disturb the balance of the impacted ecosystems (Poté et al. 2008); Haller et al. 2011). Intensive anthropogenic activities such as mining, burning of fossil fuels, agricultural practices, and discharge of industrial, urban or hospital effluents into the aquatic ecosystems are attributed to heavy metal pollution. Sediments receiving urban and hospital wastewaters under tropical conditions have been proven to contain unhealthy amounts of pathogens, ARB, ARGs, persistent organic pollutants (POPs) and heavy metals (Al Salah et al. 2019, Al Salah et al. 2020, Laffite et al. 2020, Suami et al. 2020, Anand et al. 2021, Ngweme et al. 2021). Although some bacteria have a natural ability to resist and biodegrade antibiotics, several factors favour the propagation of antibiotic resistance in microbes (Kummerer 2004, Tripathi and Cytryn 2017, Santos-Lopez et al. 2019, Baquero et al. 2021). The discharge of partially treated or untreated hospital effluents into aquatic environments complicates the issue further compared to treated wastewaters. Furthermore, abiotic factors such as heavy metals have been shown to influence ARGs' co-selection and potential to spread in the environment. For instance, several previous studies reported co-selection of ARGs in the environment by heavy metals (Dickinson et al. 2019; Mazhar et al. 2020). Consequently, the positive correlations between heavy metals, ARB and ARGs were shown to have occurred in the environment (Laffite et al. 2020, 2016). Moreover, the low concentration of toxic metals has been shown to induce ARGs' conjugative transfer (Zhang et al. 2018; Baker-Austin et al. 2006). Temperature, acidity, organic matter content and salinity of the soil/sediment influence metals' absorption rate by plants, but generally, vegetables absorb the most metals followed by roots, cereals and then fruits (Gramlich et al. 2017; McLaughlin 2016). The discharge of effluent with a relatively high metal content presents a potential health risk via direct ingestion of these metals or the selective pressure for antibiotic resistance. For example, arsenic can disturb the metabolite of cells and the process of mitosis, $\mathrm{Pb}$ causes a spectrum of diseases from arthritis to kidney and brain damage, and Cd causes nephrotoxicity (Gordon and Quastel 1948; Martin and Griswold 2009; Castagnetto et al. 2002). Also, most heavy metals cause cancer (Martin and Griswold 2009; Järup 2003). Beyond the critical role of heavy metals in ARGs' co-selection, disinfectants and pharmaceuticals beside antibiotics could promote natural transformation (Hassoun-Kheir et al. 2020). In the Democratic Republic of the Congo (DRC), the study site, Food and Agriculture Organization (FAO) supports urban gardeners through the
Urban horticulture Project, which saw 122\% increase in production in 5 years (Mutshail 2014). However, the environmental contamination of heavy metals in the freshwater resources in DRC has been considered an emerging threat to human and environmental health (Kilunga et al. 2017).

Although there are studies on ARB and ARGs in the urban river environment of DRC, most are restricted to hospital discharging points and no studies have yet been conducted to investigate the presence of heavy metals and correlating the presence of ARB and ARGs in this ecosystem (Al Salah et al. 2020). Therefore, the present study aims to determine heavy metals in the water and sediment of two river systems receiving urban and hospital effluent waters and the correlation with ARB and ARGs. The correlations will shed light on this river receiving environment for the selective pressure exerted by heavy metals on the accumulation of ARB and ARGs which has rarely been studied in a tropical system.

\section{Materials and methods}

\section{Sampling site}

According to our previous data (Al Salah et al. 2020), two river receiving systems were selected. The rivers drain through Kinshasa, the DRC capital city and receive effluent waters from two healthcare systems (a hospital and a clinic). These rivers serve as primary domestic use sources, fishing, bathing, drinking water supply and irrigation for urban agriculture, and they have a great socio-economic value. The sources of river contamination are different in both systems based on the detection of Escherichia coli upstream (Al Salah et al. 2020). In the system receiving effluent from the clinic, E. coli was detected upstream, suggesting multiple contamination sources. However, E. coli was not detected upstream in the river system receiving effluent from the hospital, suggesting the singularity of this system's pollution. The sampling took place in May/September 2019 (dry season) and October/December 2019 (wet season). Two sampling campaigns were performed during each season. The water and surface sediments $(0-3 \mathrm{~cm}$ layer) were collected in triplicate/season at the hospital/clinic effluent discharge points, and $100 \mathrm{~m}$ upstream and $100 \mathrm{~m}$ downstream. The surface sediments were chosen instead of deeper layers because it provides information on recent pollution and activities. The samples were kept at $4{ }^{\circ} \mathrm{C}$ in sterile clean plastic bottles before being shipped to the University of Geneva for analysis. The coordinates of the sampling sites are recorded in Supporting information (SI) (Table 1S). 


\section{Water and sediment physicochemical parameters}

The water physicochemical parameters including temperature (T), $\mathrm{pH}$, electrical conductivity (EC) and dissolved oxygen $\left(\mathrm{O}_{2}\right)$ values were measured in situ using a Multi 350i (WTW, Germany). A Laser Coulter LS-100 diffractometer (Beckman Coulter, Fullerton, CA, USA) was used to measure the sediment grain size including sand, silt and clay. For this analysis, the sediments were sonicated for $5 \mathrm{~min}$ in deionized water to consistently disperse the grains before being fed to the machine (Poté et al. 2008). The sediment organic matter $(\mathrm{OM})$ was determined by loss on ignition (heating to $550{ }^{\circ} \mathrm{C}$ ) for $1 \mathrm{~h}$ in Salvis oven (Salvis AG, Emmenbrücke, Luzern, Switzerland).

\section{Heavy metal analysis in water and sediment samples}

Sediment samples were lyophilized and ground to fine powder before analysis. The digestion of sediment samples was performed as described by Poté et al. (2008) with minor modification. Briefly, around $1 \mathrm{~g}$ of the ground sediments was digested in $10 \mathrm{~mL}$ of $2 \mathrm{M}$ analytical grade $\mathrm{HNO}_{3}$ in Teflon bombs at $100{ }^{\circ} \mathrm{C}$ for $16 \mathrm{~h}$. The digestion product was subsequently centrifuged for $15 \mathrm{~min}$ at $4000 \mathrm{rpm}$ and diluted 200 times in $1 \% \mathrm{HNO}_{3}$ (Suprapur® $65 \%)$. For water analysis, $9.90 \mathrm{~mL}$ of water samples was filtered through a $0.22-\mu \mathrm{m}$ syringe filter and acidified by the addition of $100 \mu \mathrm{L}$ of Suprapur®, $65 \% \mathrm{HNO}_{3}$.

Selected metals (Cr, Sc, $\mathrm{Co}, \mathrm{Ni}, \mathrm{Cu}, \mathrm{Cd}, \mathrm{Pb}$ and $\mathrm{Zn}$ ) in digested sediment and water samples were then analysed using inductive coupled plasma-mass spectroscopy (Agilent $7700 \times$ series ICP-MS, Santa Clara, USA). These metals were selected according to their toxicity occurrences in the study area (Laffite et al. 2016, 2020; Kilunga et al. 2017; Mwanamoki et al. 2015). A multi-element standard (Merck IV, KGaA-Darmstadt, Germany) solution at different concentrations $\left(0,0.2,1,5,20100\right.$, and $\left.200 \mu \mathrm{g} \mathrm{L}^{-1}\right)$ was used for calibration. The metal concentrations were expressed in ppm ( $\mathrm{mg} \mathrm{kg}^{-1}$ of dry sediment). The reference materials LKSD-3 and TMDA-51.4 for sediments and water, respectively, were used in order to verify the sensibility of the instrument and the reliability of the results. The average standard deviation of three replicates for ICPMS analysis was below 5\%, and the blanks remained undetected or below $1 \%$ of the sample signal, and the detection limit was less $0.009 \mathrm{ppm}$ for all samples. Sc was selected to be used for geochemical normalization (Mwanamoki et al. 2015). The rest of the metals were selected for their toxicity and frequency of use in the studied area.

\section{Assessment of metal pollution degree in the sediments}

Three indicators, enrichment factor $(E F)$, geoaccumulation index $\left(I_{\text {geo }}\right)$ and pollution index $(P I)$, which are important and subdivided into classes to highlight the degree of contamination were utilized to shed light on the amount of pollution in the studied region. These indicators were used to investigate the degree of sediment contamination according to Eqs. 1, 2 and 3 for $E F, I_{\text {geo }}$ and $P I$, respectively and as described below:

$E F=($ metal $/ S c)$ sample $/($ metal $/ S c)$ background

Metal: measured concentration of each metal in the sediment samples.

Sc: concentration of Scandium in analysed sediment samples

$I_{\text {geo }}=\log _{2}\left[\left(C_{n}\right) / 1.5\left(B_{n}\right)\right]$

$C_{n}$ : measured concentration of each metal in the sediment samples.

$B_{n}$ : concentration of the same metal in the geochemical background.

The values were calculated using the metal mean and lithogenic background values (Mwanamoki et al. 2015).

$P I=C_{i} / S_{i}$

$C_{i}$ : measured concentration of each metal in the sediment. $S_{i}$ : background value of each metal.

\section{Quantification of relevant bacteria and ARGs}

E. coli and Enterobacteriaceae genus were selected because of their relevance to public health and their frequency of resistance to antibiotics, particularly against $\beta$-lactams and carbapenems, which are the most prescribed antibiotics and the last resort antibiotics against Gram-negative bacteria, respectively. The extraction of bacteria and DNA was carried out as previously stated (Al Salah et al. 2020). Briefly, $10 \mathrm{~g}$ of sediment was agitated horizontally for $1 \mathrm{~h}$ in a 50 -mL solution of $0.2 \%$ sodium-hexa-metaphosphate followed by centrifugation for $15 \mathrm{~min}$ at $4000 \mathrm{rpm}$. The supernatant was utilized for bacterial quantification. The DNA was extracted from sediments using a PureLink Microbiome DNA purification kit (Invitrogen). The amount of copies of each gene was determined using quantitative PCR. The qPCR was performed using SensiFAST SYBR No-Rox kit in an Eco qPCR System (Illumina). The marker genes bla $_{T E M}$, bla $_{C T X-M}, b l a_{O X A}, b l a_{I M P}$ and 16S rRNA were targeted. We also investigated $b l a_{K P C}$ and $b l a_{S H V}$, but they were not detected anywhere in the investigated sites. The exact nature of each reaction of qPCR is reported in Table $2 \mathrm{~S}$ 
(SI). Briefly, absolute quantification of target genes was performed using ten-fold dilutions of plasmids containing an ARG or the 16S RNA insert of known concentrations. Concentrations in samples were calculated by extrapolation compared to the standard curve. Any sample with a $\mathrm{Ct}$ value lower than that of the lowest of the dilutions was considered to be undetected.

\section{Statistical analysis}

Rstudio version 1.2.5042 was used to generate statistical analysis (Team 2016). The package (Hmisc), which was developed by (Harrell, Harrell 2019), was used to generate a Pearson correlation matrix. The parameters of the matrix are metal content, organic matter content, mean grain size, which are reported in this study and total and antibioticresistant $E$. coli and Enterobacteriaceae and relevant bacterial markers and antibiotic-resistant genes in the sediments which were reported in our previous publication (Al Salah et al. 2020). The R package (ade4) was used to generate multiple principle component analysis (PCA) figures for a better visualization of the data (Dray and Dufour 2007).

\section{Results and discussion}

\section{Water physiochemical parameters}

The results of water physicochemical parameters including $\mathrm{T}, \mathrm{pH}, \mathrm{EC}$ and $\mathrm{O}_{2}$ measured during the wet and dry seasons are presented in Table $1 \mathrm{~S}$ (SI). The $\mathrm{pH}$ values from all the sampling sites were within the acceptable range set by the Food and Agriculture Organization (FAO) for water reuse. According to the $\mathrm{pH}$ readings, the waters tended to be slightly more acidic in the wet season in all the sites, except the hospital discharge point and upstream of it. These results can be explained due to the excessive rainfall during the wet season. In this study, no significant differences in temperature were noted between water samples, which could be attributed to tropical weather in Kinshasa. The electrical conductivity of most of the samples did not exceed 700 $\mu \mathrm{S} \mathrm{cm}{ }^{-1}$ set by the FAO (Ayers and Westcot 1985). These findings suggest that waters from the studied site might be used for irrigation. However, the electrical conductivity of the clinic in the dry season and downstream of the hospital in the wet season was above the $700 \mu \mathrm{S} \mathrm{cm}^{-1}$. The observed differences in the mean values of electrical conductivity can probably be attributed to high electrolytes present in the hospital effluents, which means that if these waters were to be used for irrigation, a degree of slight to moderate restriction must occur to ensure the safety of crops and farm workers (Ayers and Westcot 1985). It should be noted that local anthropogenic activities, climate and seasonality may also impact physical-chemical parameters and metal accumulation by plants. For instance, the $\mathrm{pH}$ level has an inversely proportional relation to plants' metal uptake rate, while salinity and temperature have a directly proportional relationship (McLaughlin 2016; Gramlich et al. 2017).

The results of the sediments' mean grain size and organic matter content are shown in SI (Table 3S). The sediments varied from silt at the clinic discharge point (mean grain size $=5.6 \mu \mathrm{m})$ to sand, upstream of the hospital discharge point (mean grain size $=212 \mu \mathrm{m}$ ). The organic matter content ranged from 0.12 to $7.66 \%$ with the highest recorded downstream of the hospital discharge point, followed by the hospital discharge point and the lowest upstream of the hospital discharge point. The observed organic matter content was typical for effluents with pollutants. High organic matter content begets lower metal uptake rates by crops (Gramlich et al. 2017).

\section{Metal content in water and sediments}

Table 1 summarizes the average concentrations of metals in the water samples from the study sites in the wet and dry seasons. All the metals were below the maximum limit for irrigation water. They fell below the recommended values set by sediment quality guidelines (ANZECC 2000) and the FAO's guidelines for water quality for agriculture (Ayers and Westcot 1985). However, the waters did not pass the microbiological test for irrigation water, as shown in our previous publication (Al Salah et al. 2020). The concentrations of metals in the water samples were well below the limit and had maximum values of (4.6), $\left(1.4 \times 10^{-1}\right),(8.3)$, (2.52), $\left(2.1 \times 10^{1}\right),\left(5.7 \times 10^{-1}\right),\left(5.3 \times 10^{-1}\right)$, and $\left(5.0 \times 10^{1}\right)$ $\mu \mathrm{g} \mathrm{L}^{-1}$ for $\mathrm{Cr}, \mathrm{Sc}, \mathrm{Co}, \mathrm{Ni}, \mathrm{Cu}, \mathrm{Cd}, \mathrm{Pb}$ and $\mathrm{Zn}$, respectively. The highest and lowest values of $\mathrm{Cr}$ were in the hospital effluent during the wet season and upstream of the hospital effluent during the dry season, respectively. Co remained detectable in all the sites during both seasons with the highest value recorded at the hospital discharge point in the wet season and the lowest upstream of the hospital during the wet season as well. $\mathrm{Ni}$ was the least detectable in the sites and was only detectable at the hospital discharge point in both seasons and at the clinic discharge point in the dry season. The nickel concentrations were similar to a report in China and Egypt but lower than in Mexico and South Africa (Gutiérrez et al. 2008; Li and Zhang 2010; Olujimi et al. 2015; Osman and Kloas 2010). Cu was the highest at the hospital in the wet season and was not detectable in the same site during the dry season. Copper values were lower than those reported in Nigeria, Egypt, India and South Africa (Ashokkumar et al. 2009; Ohimain et al. 2008; Olujimi et al. 2015; Osman and Kloas 2010). The highest value of Cd was recorded upstream of the hospital discharge point during the wet season. The concentrations of $\mathrm{Pb}$ were not detectable 
Table 1 The average of metal concentrations in water during the wet and dry season in micrograms per litre

\begin{tabular}{lccccccccc}
\hline Site & Season & $\mathrm{Cr}$ & $\mathrm{Sc}$ & $\mathrm{Co}$ & $\mathrm{Ni}$ & $\mathrm{Cu}$ & $\mathrm{Cd}$ & $\mathrm{Pb}$ & $\mathrm{Zn}$ \\
\hline Upstream Hospital & \multirow{2}{*}{ Dry } & 0.00 & 0.03 & 0.05 & 0.00 & 0.12 & 0.03 & 0.00 & 2.13 \\
Hospital & & 0.27 & 0.13 & 1.09 & 1.00 & 0.00 & 0.00 & 0.00 & 10.96 \\
Downstream Hospital & & 0.05 & 0.07 & 0.08 & 0.00 & 0.52 & 0.20 & 0.00 & 49.67 \\
Upstream Clinic & & 0.10 & 0.08 & 0.16 & 0.00 & 0.30 & 0.00 & 0.00 & 14.46 \\
Clinic & & 0.29 & 0.14 & 0.57 & 2.52 & 0.93 & 0.01 & 0.21 & 12.49 \\
Downstream Clinic & & 0.12 & 0.08 & 0.13 & 0.00 & 0.57 & 0.00 & 0.00 & 8.02 \\
Upstream Hospital & Wet & 0.16 & 0.00 & 0.04 & 0.00 & 0.41 & 0.57 & 0.08 & 3.14 \\
Hospital & & 4.45 & 0.00 & 8.26 & 2.52 & 21.03 & 0.02 & 0.47 & 5.86 \\
Downstream Hospital & & 0.61 & 0.00 & 0.67 & 0.00 & 2.12 & 0.01 & 0.32 & 2.48 \\
Upstream Clinic & & 0.05 & 0.06 & 0.10 & 0.00 & 0.21 & 0.01 & 0.00 & 8.30 \\
Clinic & 0.42 & 0.00 & 0.21 & 0.00 & 2.24 & 0.11 & 0.53 & 19.14 \\
Downstream Clinic & 0.09 & 0.07 & 0.10 & 0.00 & 0.55 & 0.10 & 0.00 & 28.85 \\
FAO limits (Ayers and Westcot & 100 & NA & 50 & 200 & 200 & 10 & 5000 & 2000 \\
\multicolumn{1}{l|l}{ 1985) } & & & & & & & & \\
\hline
\end{tabular}

during the dry season except at the clinic, and the highest value was recorded at the clinic discharge point during the wet season. The $\mathrm{Pb}$ concentrations were lower than those reported in South Africa and Nigeria (Ohimain et al. 2008; Olujimi et al. 2015). In both seasons, $\mathrm{Zn}$ remained detectable in all sites, and the highest value was recorded during the dry season downstream of the hospital discharge point.

Figures 1 and 2 illustrate metal contents in the sediments and the dashed lines represent the sediment quality guidelines (SQG) (Environment 2001). In general, the concentrations of metals in the sediments were higher than in water which is in agreement with the literature (Shanbehzadeh et al. 2014; Salati and Moore 2010). The metal content in the sediment samples ranged between 1.09 and 4.62, 0.21 and $0.41,0.07$ and $0.62,0$ and 6.43, 0 and 377, 0.004 and $0.021,0.038$ and 151, and 9.27 and $758 \mathrm{mg} \mathrm{kg}^{-1}$ for $\mathrm{Cr}, \mathrm{Sc}$, $\mathrm{Co}, \mathrm{Ni}, \mathrm{Cu}, \mathrm{Cd}, \mathrm{Pb}$ and $\mathrm{Zn}$, respectively. The levels of $\mathrm{Cr}$, $\mathrm{Sc}, \mathrm{Co}, \mathrm{Ni}$ and $\mathrm{Cd}$ did not exceed the maximum limits SQGs (ANZECC 2000; Environment 2001). The hospital discharge point and upstream of the clinic had acceptable levels of $\mathrm{Zn}$ while the rest of the sites exceeded the limit. When comparing the study sites to three other studies under similar circumstances of receiving wastewater effluent, the study sites contained lower levels of $\mathrm{Cd}$ and $\mathrm{Co}$ than in Croatia, Nigeria and other rivers in Kinshasa but had higher levels of $\mathrm{Cu}$ and $\mathrm{Pb}$. The Ni content was higher in Nigeria but lower than in Croatia and other sites in Kinshasa (Milaković et al. 2019; Ogwugwa et al. 2021; Laffite et al. 2016).
Fig. 1 The metal content of $\mathrm{Cr}$, $\mathrm{Sc}, \mathrm{Co}$ and $\mathrm{Ni}$ in the sediments in $\mathrm{mg} \mathrm{kg}^{-1}$ of dry weight in the log scale. The dashed line represents the limit set by the sediment quality guidelines (SQG)

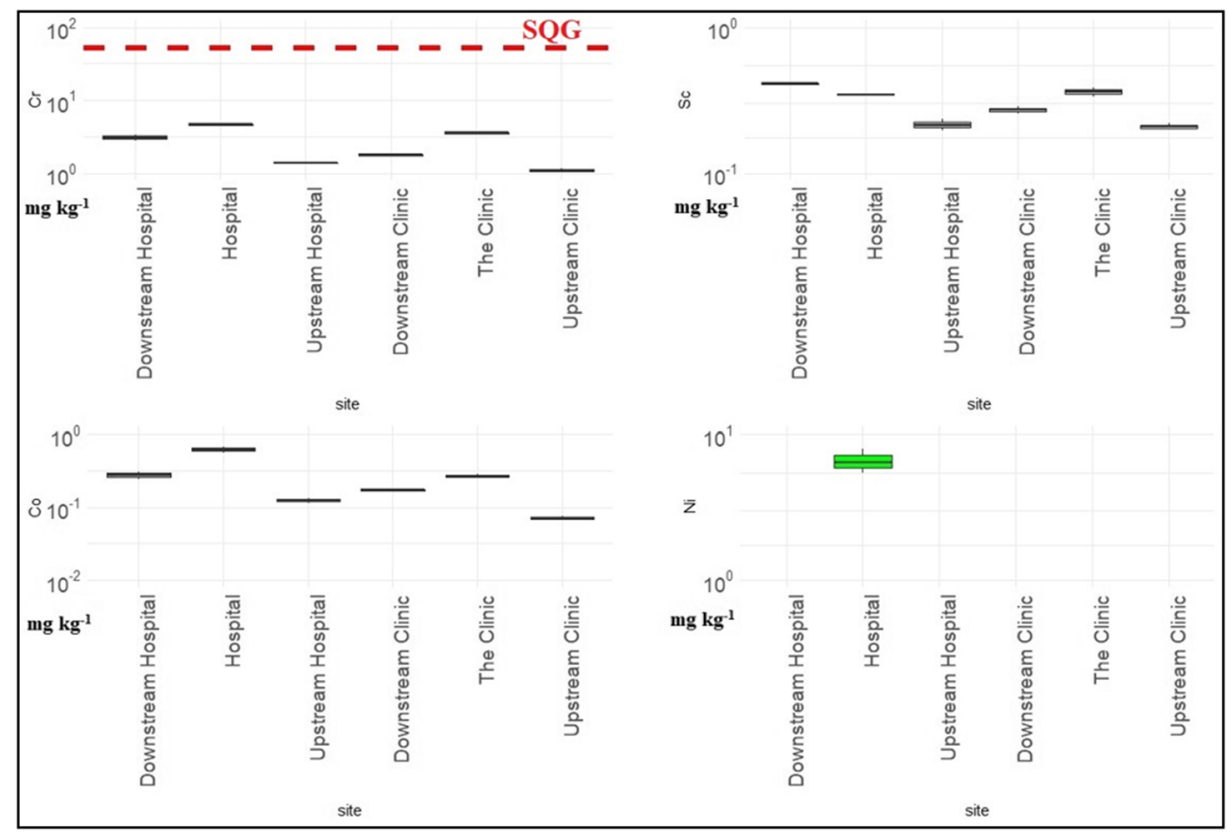


Fig. 2 The metal content of $\mathrm{Cd}$, $\mathrm{Cu}, \mathrm{Pb}$ and $\mathrm{Zn}$ in the sediments in $\mathrm{mg} \mathrm{kg}^{-1}$ of dry weight in the log scale. The dashed line represents the limit set by the sediment quality guidelines (SQG)

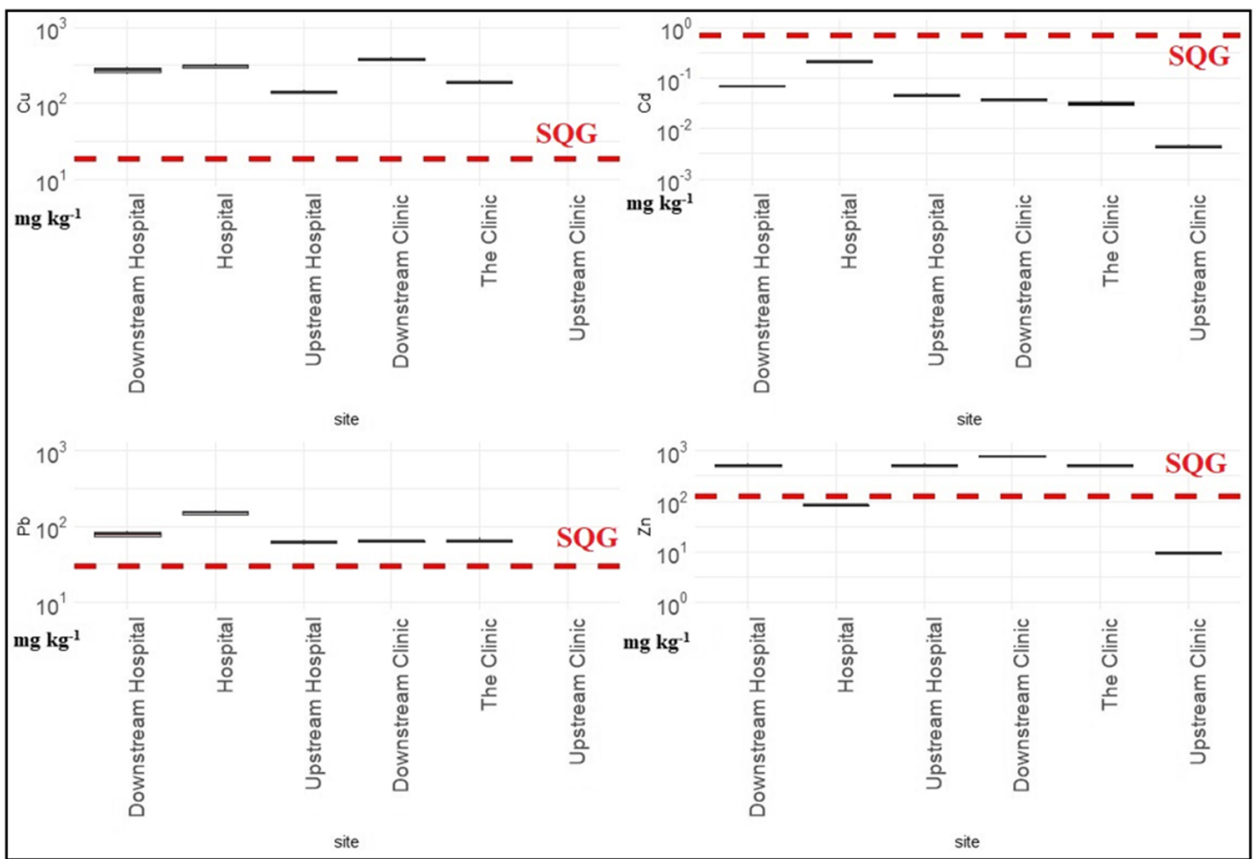

It is essential to highlight that there was not any significant difference between the discharge points and upstream of them in terms of metal content $(p>0.05)$. Therefore, we can conclude that the hospital and clinic in this study do not contribute significantly to heavy metal contamination in the area. The contamination could be attributed to other sources of contamination in particular diffuse sources such as uncontrolled landfills, agricultural runoff and various industries along these river banks. Additionally, the concentrations of fecal indicator bacteria have also been widely used to investigate freshwater pollution. It is highly recommended to utilize biological indicators instead of metal contents to investigate wastewater pollution in an area where pollution is ubiquitous because of their low cost, relative speed and convenience.

The metal pollution could accumulate and undergo biomagnification as it climbs the food web and present risk to public health. Besides, metal pollution presents a hazard to aquatic life forms and could negatively influence their otherwise stable ecosystems (Singh and Kalamdhad 2011).

\section{Assessment of metal pollution degree in the sediments}

The background data was obtained from a previous publication and the authors chose Lake Mavallee in Kinshasa to serve as a background because of its pristine nature (Mwanamoki et al. 2015). Table 2 presents the enrichment factor values based on the formula mentioned above in the "Materials and methods". Cr showed no enrichment to minor enrichment in all the sites. Co exhibited a similar pattern to $\mathrm{Cr}$ except at the hospital discharge point where Co showed moderate enrichment. Ni did not show any enrichment except moderately at the hospital discharge point. $\mathrm{Cu}$ and $\mathrm{Pb}$ showed extremely severe enrichment at all the sites except upstream of the clinic which had no enrichment. Cd enrichment degree varied from no enrichment to severe enrichment at the hospital discharge point. Zn underwent severe enrichment upstream of the clinic and extremely severe enrichment in all the other sites.

Table 2 Classification of elemental enrichment and pollution based on the $E F$ and geoaccumulation index. The key to the color-coding is below the table

\begin{tabular}{|c|c|c|c|c|c|c|c|c|c|c|c|c|c|c|}
\hline \multirow[b]{2}{*}{ Site } & \multicolumn{7}{|c|}{ EF } & \multicolumn{7}{|c|}{ Igeo } \\
\hline & $\mathrm{Cr}$ & Co & $\mathbf{N i}$ & $\mathrm{Cu}$ & Cd & $\mathbf{P b}$ & Zn & $\mathrm{Cr}$ & Co & $\mathbf{N i}$ & $\mathrm{Cu}$ & Cd & $\mathbf{P b}$ & Zn \\
\hline Downstream Hospital & 1.15 & 1.73 & 0.00 & 200 & 4.2 & 104 & 308 & -2.5 & -1.9 & 0.0 & 4.9 & -0.6 & 4.0 & 5.6 \\
\hline Hospital & 2.06 & 4.63 & 4.25 & 269 & 15.5 & 238 & 60 & -1.9 & -0.7 & -0.9 & 5.1 & 1.0 & 4.9 & 2.9 \\
\hline Upstream Hospital & 0.99 & 1.50 & 0.00 & 197 & 5.4 & 157 & 582 & -3.7 & -3.1 & 0.0 & 4.0 & -1.2 & 3.7 & 5.5 \\
\hline Downstream Clinic & 1.01 & 1.64 & 0.00 & 421 & 3.4 & 127 & 695 & -3.3 & -2.6 & 0.0 & 5.4 & -1.5 & 3.7 & 6.1 \\
\hline The Clinic & 1.52 & 1.92 & 0.00 & 159 & 2.2 & 98 & 345 & -2.3 & -1.9 & 0.0 & 4.4 & -1.8 & 3.7 & 5.5 \\
\hline Upstream Clinic & 0.81 & 0.88 & 0.00 & 0.00 & 0.53 & 0.99 & 11 & -4.0 & -3.9 & 0.0 & 0.0 & -4.6 & -3.7 & -0.2 \\
\hline
\end{tabular}


Table 2 (continued)

$\mathrm{EF}<1$
$\mathrm{EF}<3$
EF $3-5$
EF $5-10$
EF $10-25$
EF $25-50$
EF $>50$

no enrichment

minor enrichment

moderate enrichment

moderately severe enrichment

severe enrichment

very severe enrichment

extremely severe enrichment
The degree of pollution exhibited in Table 2 is based on the geo accumulation index. Upstream of the clinic discharge point remained pollution-free. All the sites had class 0 (practically unpolluted) for $\mathrm{Cr}, \mathrm{Co}, \mathrm{Ni}$ and $\mathrm{Cd}$ pollution except for $\mathrm{Cd}$ at the hospital discharge point with class 2 (moderately polluted). The $\mathrm{Cu}$ pollution was classified as class 4 (heavily polluted) upstream of the hospital, as class 5 (heavily to extremely polluted) downstream of the hospital and at the clinic discharge point and as class 6 (extremely polluted) at hospital discharge point and downstream of the clinic. $\mathrm{Pb}$ pollution was designated as class 4 upstream of the hospital, downstream of the clinic and the clinic's discharge point and as class 5 discharge point of the hospital and downstream of it. $\mathrm{Zn}$ pollution scored class 6 in all the sites except at the hospital discharge point, which scored class 3 (moderately to heavily polluted), and upstream of the clinic which was unpolluted. The results highlight the high metal concentrations in all sampling sites, reaching values (in $\mathrm{m} \mathrm{kg}^{-1}$ ) of $\mathrm{Cu}$ (140-377), $\mathrm{Pb}(62-151)$ and $\mathrm{Zn}$ (83-758). According to the enrichment factor $(E F)$, results showed extremely severe enrichment of $\mathrm{Cu}(159 \leq E F \leq 421), \mathrm{Pb}(98 \leq E F \leq 238)$ and $\mathrm{Zn}(60 \leq E F \leq \mathrm{Zn})$ and extreme pollution as indicated by high geoaccumulation indices $\left(I_{\text {geo }}\right)$, which were $\left(4.0 \leq I_{\text {geo }} \leq 5.4\right)$, $\left(3.7 \leq I_{\text {geo }} \leq 4.9\right)$ and $\left(2.9 \leq I_{\text {geo }} \leq 6.1\right)$, for $\mathrm{Cu}, \mathrm{Pb}$ and $\mathrm{Zn}$, respectively.

When comparing the $E F$ and $I_{\text {geo }}$ scores with rivers receiving wastewater effluent, our study sites scored higher enrichment and pollution of $\mathrm{Cu}, \mathrm{Pb}$ and $\mathrm{Zn}$ but scored lower scores for $\mathrm{Cd}, \mathrm{Cr}$ and $\mathrm{Ni}$ than in other urban rivers under tropical conditions (Hanif et al. 2016; Kilunga et al. 2017; Salati and Moore 2010).

Igeo $\leq 0$
$0<$ Igeo $<1$
$1<$ Igeo $<2$
$2<$ Igeo $<3$
$3<$ Igeo $<4$
$4<$ Igeo $<5$
$5<$ Igeo

Class 0 - practically unpolluted Class 1 - unpolluted to moderately polluted Class 2 - moderately polluted Class 3 - moderately to heavily polluted Class 4 - heavily polluted Class 5 - heavily to extremely polluted Class 6 - extremely polluted
The $P I$ results (Table 3 ) concurred with the $I_{\text {geo }}$ and indicated very strong levels of $\mathrm{Cu}, \mathrm{Pb}$ and $\mathrm{Zn}$ pollution in all the sites except for upstream of the hospital and high level of $\mathrm{Cd}$ pollution only at the hospital discharge point. When comparing the $E F$ and $I_{\text {geo }}$ scores with rivers receiving wastewater effluent, our study sites scored higher enrichment and pollution of $\mathrm{Cu}, \mathrm{Pb}$ and $\mathrm{Zn}$ than in other rivers in Kinshasa, DRC, Iran and Pakistan but scored lower scores for $\mathrm{Cd}, \mathrm{Cr}$ and Ni (Hanif et al. 2016; Kilunga et al. 2017; Salati and Moore 2010).

\section{Quantification of relevant bacteria, 16 s rDNA, ARGs and bacterial markers}

The abundances of total and ARB indicators in water and sediments are illustrated in Fig. 1S and $2 \mathrm{~S}$ (Supporting information (SI)), respectively. The $16 \mathrm{~S}$ rRNA was quantified per gram of dry sediment (Fig. 3S), and bacterial markers and ARGs were expressed in relation to the total copies of 16 s rDNA, as shown in Figs. 4S and 5S (SI). We also investigated $b l a_{K P C}$ and $b l a_{S H V}$, but they were not detected anywhere in the investigated sites. This section has been discussed in depth previously (Al Salah et al. 2020).

In the dry season, the amounts of cultivable total and antibiotic-resistant E. coli and Enterbacteriaceae from the sediment were generally lower than the wet season, which is in agreement with a study performed in Nigeria (Achudume and Olawale 2009). However, the exact opposite is true for the water. The abundances in water were higher during the dry season, which could be attributed to the dilution by runoff as concluded by studies conducted under similar tropical
Table 3 Classification of elemental pollution based on the pollution index

\begin{tabular}{llllllll}
\hline Site & $\mathrm{Cr}$ & $\mathrm{Co}$ & $\mathrm{Ni}$ & $\mathrm{Cu}$ & $\mathrm{Cd}$ & $\mathrm{Pb}$ & $\mathrm{Zn}$ \\
\hline Downstream hospital & 0 & 0 & 0 & $\mathbf{4 6}$ & 1 & $\mathbf{2 4}$ & $\mathbf{7 1}$ \\
Hospital & 0 & 1 & 1 & $\mathbf{5 2}$ & 3 & $\mathbf{4 6}$ & $\mathbf{1 2}$ \\
Upstream hospital & 0 & 0 & 0 & $\mathbf{2 4}$ & 1 & $\mathbf{1 9}$ & $\mathbf{7 0}$ \\
Downstream clinic & 0 & 0 & 0 & $\mathbf{6 4}$ & 1 & $\mathbf{1 9}$ & $\mathbf{1 0 6}$ \\
Clinic & 0 & 0 & 0 & $\mathbf{3 2}$ & 0 & $\mathbf{2 0}$ & $\mathbf{7 0}$ \\
Upstream clinic & 0 & 0 & 0 & 0 & 0 & 0 & 1 \\
\hline
\end{tabular}

$P I$ values are classified as the following: not polluted $(P I<1)$, low level of pollution $(1 \geq P I<2)$, moderate level of pollution $(2 \geq P I<3)$ assigned in italics, strong level of pollution $(3 \geq P I<5)$ or very strong level of pollution $(P I>5)$ assigned in bold 
conditions in Vietnam and India (Hoa et al. 2011; Pathak et al. 1993). The most widespread of ARGs was bla ${ }_{C T X-M}$ (Canton et al. 2012). Hospitals play a crucial role in the widespread of ARB and ARGs (Rodriguez-Mozaz et al. 2015; Graham et al. 2011; Xu et al. 2015; Calero-Caceres et al. 2017).

\section{Statistical analysis and correlation between metal and biological parameters}

Several analysed parameters were used to construct a Pearson correlation matrix of which two were physical characteristics of the sediments (grain size and organic content), eight were metal contents in the sediments, and 13 were biological indicators (four relevant bacterial markers, four ARGs, and five total and antibiotic-resistant indicators), as shown in Table 4. The total 16S rRNA, E. coli (uidA), Pseudomonas, Enterococcus and ARGs were quantified using quantitative polymerase reaction (qPCR), and $\beta$-lactam, carbapenemresistant and total Enterobacteriaceae and E. coli were quantified using culture-based methods, as described and reported in our previous publication (Al Salah et al. 2020).

$\mathrm{Cr}$ correlated at the $0.01 p$-level negatively with grain size and positively with the total 16S rRNA, Enterococcus, bla $_{I M P}$, all the metals except for Zn, $\beta$-lactam, carbapenem-resistant and total Enterobacteriaceae. Cr also correlated positively at the 0.05 level with Pseudomonas, bla $a_{C T X-M}$ and organic matter content. Co correlated at the 0.01 level negatively with grain size and positively with 16S rRNA, Pseudomonas, organic matter, $\mathrm{Ni}, \mathrm{Cu}, \mathrm{Cd}, \mathrm{Pb}$, carbapenem-resistant and total Enterobacteriaceae. Co also correlated positively at the 0.05 level with Enterococcus and bla $a_{C T X-M}$. Ni correlated positively at the 0.01 level with Pseudomonas, $\mathrm{Cu}, \mathrm{Cd}, \mathrm{Pb}$, carbapenem-resistant and total Enterobacteriaceae. $\mathrm{Ni}$ also correlated at the 0.05 level positively with $b l a_{C T X-M}$ and negatively with $\mathrm{Zn}$ and E. coli. Cu correlated at the 0.01 level negatively with grain size and positively with $16 \mathrm{~S}$ rRNA, Enterococcus, organic matter, $\mathrm{Cd}, \mathrm{Pb}$, carbapenem-resistant and total Enterobacteriaceae. $\mathrm{Cu}$ also correlated positively at the 0.05 level with Pseudomonas, bla $a_{C T X-M}$, bla $_{T E M}, \mathrm{Zn}$ and E. coli. Cd correlated at the 0.01 level negatively with grain size and positively with $16 \mathrm{~S}$ rRNA, Pseudomonas, organic matter, $\mathrm{Pb}$, carbapenem-resistant and total Enterobacteriaceae. Cd also correlated positively at the 0.05 level with $16 \mathrm{~S}$ rRNA and $b l a_{C T X-M} . \mathrm{Pb}$ correlated at the 0.01 level negatively with grain size and positively with $16 \mathrm{~S}$ rRNA, Pseudomonas, bla ${ }_{C T X-M}$, organic matter,

Table 4 Pearson correlation matrix between metal content, physicochemical parameters and biologically relevant bacteria and genes. $(*)$ means significant at the 0.05 level. $(* *)$ means significant at the 0.01 level

\begin{tabular}{|c|c|c|c|c|c|c|c|}
\hline & $\mathrm{Cr}$ & Co & $\mathrm{Ni}$ & $\mathrm{Cu}$ & $\mathrm{Cd}$ & $\mathrm{Pb}$ & $\mathrm{Zn}$ \\
\hline $\mathrm{OM}$ & $0.50 *$ & $0.54 * *$ & 0.35 & $0.79 * *$ & $0.58 * *$ & $0.64 * *$ & 0.29 \\
\hline Grain size & $-0.90 * *$ & $-0.70 * *$ & -0.34 & $-0.93 * *$ & $-0.54 * *$ & $-0.79 * *$ & $-0.66^{* *}$ \\
\hline $16 \mathrm{~s}$ & $0.61 * *$ & $0.52 * *$ & 0.35 & $0.55^{* *}$ & $0.42 *$ & $0.54 * *$ & 0.26 \\
\hline E. coli (uidA) & 0.05 & -0.03 & -0.22 & 0.30 & -0.04 & 0.07 & $0.45^{*}$ \\
\hline Enterococcus & $0.62 * *$ & $0.43 *$ & 0.16 & $0.62 * *$ & 0.30 & $0.51 *$ & $0.53 * *$ \\
\hline Pseudomonas & $0.51 *$ & $0.65^{* *}$ & $0.69 * *$ & $0.42 *$ & $0.67 * *$ & $0.60 * *$ & -0.30 \\
\hline$b l a_{O X A}$ & 0.39 & 0.12 & -0.17 & 0.34 & -0.06 & 0.19 & $0.65 * *$ \\
\hline$b l a_{C T X-M}$ & $0.48^{*}$ & $0.51 *$ & $0.44^{*}$ & $0.48^{*}$ & $0.50 *$ & $0.52 * *$ & 0.01 \\
\hline$b l a_{I M P}$ & $0.53 * *$ & 0.36 & 0.21 & 0.28 & 0.19 & 0.34 & 0.25 \\
\hline$b l a_{T E M}$ & 0.32 & 0.34 & 0.25 & $0.43 *$ & 0.35 & 0.38 & 0.11 \\
\hline E. coli & 0.24 & -0.09 & $-0.49 *$ & $0.45 *$ & -0.24 & 0.08 & $0.99 * *$ \\
\hline Enterobacteriaceae & $0.89 * *$ & $0.90 * *$ & $0.83^{* *}$ & $0.64 * *$ & $0.81 * *$ & $0.85^{* *}$ & -0.09 \\
\hline B-lactam-resistant $E$. coli & 0.22 & -0.12 & -0.33 & -0.01 & -0.34 & -0.10 & $0.56 * *$ \\
\hline B-lactam-resistant Enterobacteriaceae & $0.53 * *$ & 0.27 & 0.08 & 0.23 & 0.05 & 0.26 & 0.39 \\
\hline Carbapenem-resistant Enterobacteriaceae & $0.73 * *$ & $0.93 * *$ & $1.00 * *$ & $0.58^{* *}$ & $0.96 * *$ & $0.85^{* *}$ & $-0.44^{*}$ \\
\hline $\mathrm{Cr}$ & & $0.92 * *$ & $0.69 * *$ & $0.91 * *$ & $0.81 * *$ & $0.95 * *$ & 0.28 \\
\hline Co & & & $0.91 * *$ & $0.84 * *$ & $0.97 * *$ & $0.99 * *$ & -0.07 \\
\hline $\mathrm{Ni}$ & & & & $0.56^{* *}$ & $0.96 * *$ & $0.83 * *$ & $-0.48^{*}$ \\
\hline $\mathrm{Cu}$ & & & & & $0.76 * *$ & $0.92 * *$ & $0.43^{*}$ \\
\hline $\mathrm{Cd}$ & & & & & & $0.94 * *$ & -0.26 \\
\hline $\mathrm{Pb}$ & & & & & & & 0.08 \\
\hline $\mathrm{Zn}$ & & & & & & & \\
\hline
\end{tabular}




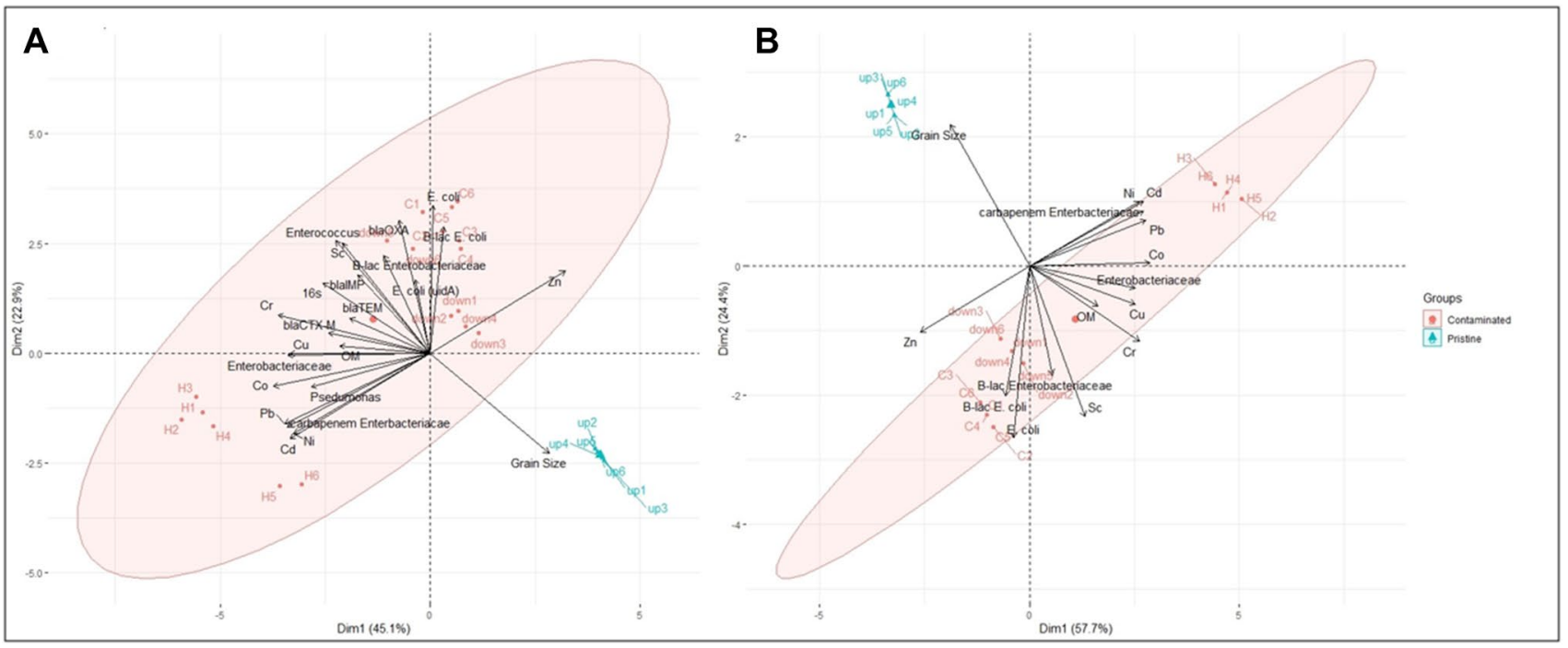

Fig. 3 Principle component analyses $\mathbf{A}$ based on all biological and physical parameters and $\mathbf{B}$ based only on indicator bacteria, ARB and metals. $\mathrm{H}$ stands for hospital, $\mathrm{C}$ for clinic, up for upstream and down for downstream

carbapenem-resistant and total Enterobacteriaceae. $\mathrm{Pb}$ also correlated with Enterococcus at the 0.05 level. $\mathrm{Zn}$ correlated at the 0.01 level negatively with grain size and positively with Enterococcus, bla ${ }_{O X A}$, $\beta$-lactam-resistant and total E. coli. Zn also correlated at the 0.05 level positively with $E$. coli (uidA) and negatively with carbapenemresistant Enterobacteriaceae.

Three PCA were performed. The first PCA utilized all the biological and metal parameters, which results from two distinguished clusters based on a total variance of $68 \%$ as displayed in Fig. 3A. Similarly, the second PCA utilized only indicator bacteria, ARB and metals, which also displays two distinct clusters based on a total variance of $82.1 \%$, as shown in Fig. 3B. However, the third PCA was performed based only on the metal content and resulted in overlapping clusters, as shown in supplementary data (Fig. 6S), which support the previous hypothesis that utilizing biological indicators is a better approach to monitor pollution from wastewaters in the developing world than metal content. All the metals except for $\mathrm{Zn}$ correlated positively with one another which suggest a similar contamination source or a similar transport and retention pathway due to their positive charge (Karathanasis 1999; Naidu et al. 1994; Naidu et al. 1998; Sherene 2010). In general, the metals correlated positively with organic matter content and negatively with grain size. All of the studied metals correlated positively with at least one ARG, which could be attributed to the expression of metal resistance by those genes which have been reported extensively in the literature (Knapp et al. 2011; Laffite et al. 2016; Imran et al. 2019; Nguyen et al. 2019; Di Cesare et al. 2016).

\section{Conclusion}

Each of the studied metals correlated significantly and positively with at least one ARG, suggesting the selection pressure of metals to antibiotic resistance. The levels of enrichment were extremely severe for $\mathrm{Cu}, \mathrm{Pb}$ and $\mathrm{Zn}$. However, the contribution of hospital effluent to the metal pollution was not significant in these study sites because of the lack of infrastructure and random unauthorized landfills and littering, which is ubiquitous in Kinshasa (DRC). Thus, this study showed varying influence on the ARG co-selection by river receiving systems. Therefore, we highly recommend utilizing biological indicators when investigating pollution in a city that lacks adequate infrastructure. Biological indicators are faster, cheaper and more convenient than metal content analysis. This is more important in countries where environmental regulations are often inadequate, and infrastructure is lacking. The findings can be helpful for the management of landfills and the establishment of adequate infrastructure to limit the spread of the contaminants to freshwater environments. This study will provide baseline information for the parameters relevant for the spreading of ARB, which will be an important measure to design strategies to control the metals, resistant bacteria and ARGs in the environment.

Supplementary Information The online version contains supplementary material available at https://doi.org/10.1007/s11356-021-17115-z.

Author contribution JP, PS, AL and DMAS conceived and designed the research; DMAS performed the research and laboratory analysis; all the authors analysed the data, wrote the paper, have read, reviewed and approved the manuscript before submission. 
Funding Open access funding provided by University of Geneva. We are grateful to the financial support from King Abdulaziz City for Science and Technology and the Saudi Arabian Cultural Mission (Scholarship no. 11432).

\section{Declarations}

Ethics approval Not applicable.

Consent to participate Not applicable.

Consent for publication All authors have checked the manuscript and have agreed to the publication on Environmental Science and Pollution Research.

Conflict of interest The authors declare no competing interests.

Open Access This article is licensed under a Creative Commons Attribution 4.0 International License, which permits use, sharing, adaptation, distribution and reproduction in any medium or format, as long as you give appropriate credit to the original author(s) and the source, provide a link to the Creative Commons licence, and indicate if changes were made. The images or other third party material in this article are included in the article's Creative Commons licence, unless indicated otherwise in a credit line to the material. If material is not included in the article's Creative Commons licence and your intended use is not permitted by statutory regulation or exceeds the permitted use, you will need to obtain permission directly from the copyright holder. To view a copy of this licence, visit http://creativecommons.org/licenses/by/4.0/.

\section{References}

Achudume AC, Olawale JT (2009) Occurrence of antibiotic resistant bacteria in waste site of Ede south west Nigeria. J Environ Biol 30:187-189

Salah Al, Dhafer MM, Laffite A, Poté J (2019) Occurrence of bacterial markers and antibiotic resistance genes in sub-Saharan rivers receiving animal farm wastewaters. Sci Rep 9:14847

Al Salah, Dhafer Mohammed M., Georgette N. Ngweme, Amandine Laffite, Jean-Paul Otamonga, Crispin Mulaji, and John Poté. 2020. Hospital wastewaters: a reservoir and source of clinically relevant bacteria and antibiotic resistant genes dissemination in urban river under tropical conditions. Ecotoxicol Environ Safety, 200: 110767

Anand U, Reddy B, Singh VK, Singh AK, Kesari KK, Tripathi P, Kumar P, Tripathi V, Simal-Gandara J (2021) Potential environmental and human health risks caused by antibiotic-resistant bacteria (ARB), antibiotic resistance genes (ARGs) and emerging contaminants (ECs) from municipal solid waste (MSW) landfill. Antibiotics 10(4):374

ANZECC, ARMCAZ. (2000) Sediment quality guidelines (in) Australian and New Zealand guidelines for fresh and marine water quality. In

Ashokkumar S, Mayavu P, Sampathkumar P, Manivasagam P, Rajaram G, Marinebiology CAS, Nadu T (2009) Seasonal distribution of heavy metals in the Mullipallam creek of Muthupettai mangroves (southeast coast of India). American-Eurasian J Sci Res 4:308-312

Ayers RS, Westcot DW (1985) Water quality for agriculture (Food and Agriculture Organization of the United Nations Rome).
Baker-Austin C, Wright MS, Stepanauskas R, McArthur JV (2006) Co-selection of antibiotic and metal resistance. Trends Microbiol 14:176-182

Baquero F, Martinez JL, Lanza VF, Rodríguez-Beltrán J, Galán JC, San Millán A, Cantón R, Coque TM (2021) Evolutionary pathways and trajectories in antibiotic resistance. Clin Microbiol Rev 34:e0050-e119

Calero-Caceres W, Mendez J, Martin-Diaz J, Muniesa M (2017) The occurrence of antibiotic resistance genes in a Mediterranean river and their persistence in the riverbed sediment. Environ Pollut 223:384-394

Canton R, Jose MGA, Galan JC (2012) CTX-M enzymes: origin and diffusion. Front Microbiol, 3

Castagnetto JM, Hennessy SW, Roberts VA, Getzoff ED, Tainer JA, Pique ME (2002) MDB: the metalloprotein database and browser at The Scripps Research Institute. Nucleic Acids Res 30:379-382

Daily GC, Postel S, Bawa K, Kaufman L, Peterson CH, Carpenter S, Tillman D, Dayton P, Alexander S, Lagerquist K (2012) Nature's services: societal dependence on natural ecosystems (Island Press).

Devarajan N, Laffite A, Mulaji CK, Otamonga JP, Mpiana PT, Mubedi JI, Prabakar K, Ibelings BW, Poté J (2016) Occurrence of Antibiotic Resistance Genes and Bacterial Markers in a Tropical River Receiving Hospital and Urban Wastewaters. PLoS One 11(2)

Di Cesare A, Eckert E, Corno G (2016) Co-selection of antibiotic and heavy metal resistance in freshwater bacteria. J Limnol, 75

Dickinson AW, Power A, Hansen MG, Brandt KK, Piliposian G, Appleby P, PA O'neill, RT Jones, P Sierocinski, Koskella B (2019) Heavy metal pollution and co-selection for antibiotic resistance: a microbial palaeontology approach. Environ Int, 132: 105117

Devarajan N, Laffite A, Ngelikoto P, Elongo V, Prabakar K, Mubedi JI, Piana PTM, Wildi W, Poté J (2015) Hospital and urban effluent waters as a source of accumulation of toxic metals in the sediment receiving system of the Cauvery River, Tiruchirappalli, Tamil Nadu. India Environmental Science and Pollution Research 22(17):12941-12950

Dray, Stéphane, and Anne-Béatrice Dufour. 2007. The ade4 package: implementing the duality diagram for ecologists, 2007, 22: $20 \% \mathrm{~J}$ Journal of Statistical Software.

Environment, Canadian Council of Ministers of the. (2001) Canadian sediment quality guidelines for the protection of aquatic life: summary tables. Updated, Canadian environmental quality guidelines, 1999

Gordon JJ, Quastel JH (1948) Effects of organic arsenicals on enzyme systems. Biochemical Journal 42:337-350

Graham DW, Olivares-Rieumont S, Knapp CW, Lima L, Werner D, Bowen E (2011) Antibiotic resistance gene abundances associated with waste discharges to the Almendares River near Havana Cuba. Environ Sci Technol 45:418-424

Gramlich A, Susan Tandy C, Andres JC, Paniagua LA, Schneider M, Schulin R (2017) Cadmium uptake by cocoa trees in agroforestry and monoculture systems under conventional and organic management. Sci Total Environ 580:677-686

Gutiérrez RL, Rubio-Arias H, Quintana R, Ortega JA, Gutierrez M (2008) Heavy metals in water of the San Pedro River in Chihuahua, Mexico and its potential health risk. Int J Environ Res Public Health 5:91-98

Haller L, Tonolla M, Zopfi J, Peduzzi R, Wildi W, Poté J (2011) Composition of bacterial and archaeal communities in freshwater sediments with different contamination levels (Lake Geneva, Switzerland). Water Res 45:1213-1228

Hanif N, Eqani SAMAS, Ali SM, Cincinelli A, Ali N, Katsoyiannis IA, Tanveer ZI, Bokhari H (2016) Geo-accumulation and enrichment 
of trace metals in sediments and their associated risks in the Chenab River Pakistan. J Geochem Explor 165:62-70

Harrell Jr, Frank E, Maintainer Frank E Harrell Jr. (2019) Package 'Hmisc', CRAN2018, 2019: 235-6

Hassoun-Kheir, Nasreen, Yoav Stabholtz, Jan-Ulrich Kreft, Roberto de la Cruz, Jesús L Romalde, Joseph Nesme, Søren J Sørensen, Barth F Smets, David Graham, and Mical Paul. (2020). Comparison of antibiotic-resistant bacteria and antibiotic resistance genes abundance in hospital and community wastewater: a systematic review, Sci Total Environ: 140804

Hoa PT, Managaki S, Nakada N, Takada H, Shimizu A, Anh DH, Viet PH, Suzuki S (2011) Antibiotic contamination and occurrence of antibiotic-resistant bacteria in aquatic environments of northern Vietnam. Sci Total Environ 409:2894-2901

Imran Md, Das KR, Naik MM (2019) Co-selection of multi-antibiotic resistance in bacterial pathogens in metal and microplastic contaminated environments: an emerging health threat. Chemosphere 215:846-857

Järup L (2003) Hazards of heavy metal contamination. Br Med Bull $68: 167-182$

Karathanasis AD (1999) Subsurface migration of copper and zinc mediated by soil colloids. Soil Sci Soc Am J 63:830-838

Ki-moon B, UN Secretary General (2010) The human right to water and sanitation, Media Brief at the United Nations General Assembly-28 July

Kilunga, Pitchouna I, Periyasamy Sivalingam, Amandine Laffite, Dominique Grandjean, Crispin K. Mulaji, Luiz Felippe de Alencastro, Pius T. Mpiana, and John Poté (2017) Accumulation of toxic metals and organic micro-pollutants in sediments from tropical urban rivers, Kinshasa, Democratic Republic of the Congo, Chemosphere, 179: 37-48

Knapp, Charles W, Seánín M McCluskey, Brajesh K Singh, Colin D Campbell, Gordon Hudson, and David W Graham. (2011) Antibiotic resistance gene abundances correlate with metal and geochemical conditions in archived Scottish soils, Plos One, 6: e27300.

Kummerer K (2004) Resistance in the environment. J Antimicrob Chemother 54:311-320

Laffite A, Kilunga PI, Kayembe JM, Devarajan N, Mulaji CK, Giuliani G, Slaveykova VI, Pote J (2016) Hospital effluents are one of several sources of metal, antibiotic resistance genes, and bacterial markers disseminated in sub-Saharan urban rivers, Front Microbiol 7

Laffite, Amandine, Dhafer Mohammed M. Al Salah, Vera I. Slaveykova, Jean-Paul Otamonga, and John Poté (2020) Impact of anthropogenic activities on the occurrence and distribution of toxic metals, extending-spectra $\beta$-lactamases and carbapenem resistance in sub-Saharan African urban rivers. Sci Total Environ, 727: 138129

Li S, Zhang Q (2010) Spatial characterization of dissolved trace elements and heavy metals in the upper Han River (China) using multivariate statistical techniques. J Hazard Mater 176:579-588

Martin S, Griswold W (2009) Human health effects of heavy metals. Environ Sci Technol Briefs Citizens 15:1-6

Mazhar, Sohaib H, Xuanji Li, Azhar Rashid, JunMing Su, Junqiang $\mathrm{Xu}$, Asker Daniel Brejnrod, Jian-Qiang Su, Yijian Wu, YongGuan Zhu, and Shun Gui Zhou (2020) Co-selection of antibiotic resistance genes, and mobile genetic elements in the presence of heavy metals in poultry farm environments. Sci Total Environ, 755: 142702

McLaughlin M (2016) Heavy metals in agriculture with a focus on cadmium. In Congreso Ecuatoriano de la Ciencia del SueloXV

Milaković M, Vestergaard G, González-Plaza JJ, Petrić I, Šimatović A, Senta I, Kublik S, Schloter M, Smalla K, Udiković-Kolić N (2019) Pollution from azithromycin-manufacturing promotes macrolide-resistance gene propagation and induces spatial and seasonal bacterial community shifts in receiving river sediments. Environ Int 123:501-511

Mutshail G (2014) Technological overview on urban and peri-urban horticulture in DRC-Case Lubumbashi

Mwanamoki PM, Devarajan N, Niane B, Ngelinkoto P, Thevenon F, Nlandu JW, Mpiana PT, Prabakar K, Mubedi JI, Kabele CG, Wildi W, Poté J (2015) Trace metal distributions in the sediments from river-reservoir systems: case of the Congo River and Lake Ma Vallée, Kinshasa (Democratic Republic of Congo). Environ Sci Pollut Res 22:586-597

Naidu R, Sumner ME, Harter RD (1998) Sorption of heavy metals in strongly weathered soils: an overview. Environ Geochem Health 20:5-9

Naidu R, Bolan NS, Kookana RS, Tiller KG (1994) Ionic-strength and $\mathrm{pH}$ effects on the sorption of cadmium and the surface charge of soils. Eur J Soil Sci 45:419-429

Nguyen CC, Hugie CN, Kile ML, Navab-Daneshmand T (2019) Association between heavy metals and antibiotic-resistant human pathogens in environmental reservoirs: a review. Front Environ Sci Eng 13:46

Ngweme, Georgette N., Dhafer Mohammed M. Al Salah, Amandine Laffite, Periyasamy Sivalingam, Dominique Grandjean, Joel N. Konde, Crispin K. Mulaji, Florian Breider, and John Poté. (2021) Occurrence of organic micropollutants and human health risk assessment based on consumption of Amaranthus viridis, Kinshasa in the Democratic Republic of the Congo. Sci Total Environ, 754: 142175

Ogwugwa, Vincent Happy, Ganiyu Oladunjoye Oyetibo, and Olukayode Oladipupo Amund. (2021) Taxonomic profiling of bacteria and fungi in freshwater sewer receiving hospital wastewater. Environ Res 192: 110319

Ohimain EI, Jonathan G, Abah SO (2008) Variations in heavy metal concentrations following the dredging of an oil well access canal in the Niger Delta. Adv Biol Res 2:97-103

Olujimi, OO, OS Fatoki, JP Odendaal, and OU Oputu (2015) Variability in heavy metal levels in river water receiving effluents in Cape Town, South Africa, Research and practices in water quality: 193-211

Osman AGM, Kloas W (2010) Water quality and heavy metal monitoring in water, sediments, and tissues of the African Catfish Clarias gariepinus (Burchell, 1822) from the River Nile, Egypt. J Environ Prot 1:389

Pathak SP, Bhattacherjee JW, Ray PK (1993) Seasonal-variation in survival and antibiotic-resistance among various bacterialpopulations in a tropical river. J Gen Appl Microbiol 39:47-56

Poté J, Haller L, Loizeau J-L, Bravo AG, Sastre V, Wildi W (2008) Effects of a sewage treatment plant outlet pipe extension on the distribution of contaminants in the sediments of the Bay of Vidy Lake Geneva, Switzerland. Bioresource Technol 99:7122-7131

Rodriguez-Mozaz S, Chamorro S, Marti E, Huerta B, Gros M, Sanchez-Melsio A, Borrego CM, Barcelo D, Balcazar JL (2015) Occurrence of antibiotics and antibiotic resistance genes in hospital and urban wastewaters and their impact on the receiving river. Water Res 69:234-242

Salati S, Moore F (2010) Assessment of heavy metal concentration in the Khoshk River water and sediment Shiraz, Southwest Iran. Environ Monit Assess 164:677-689

Sanderson H, Fricker C, Brown RS, Majury A, Liss SN (2016) Antibiotic resistance genes as an emerging environmental contaminant. Environ Rev 24:205-218

Sivalingam P, Poté J, Prabakar K (2020) Extracellular DNA (eDNA): neglected and potential sources of antibiotic resistant genes (ARGs) in the aquatic environments. Pathogens 9:874. https:// doi.org/10.3390/pathogens 9110874

Santos-Lopez, Alfonso, Christopher W Marshall, Michelle R Scribner, Daniel J Snyder, and Vaughn S Cooper. (2019) Evolutionary 
pathways to antibiotic resistance are dependent upon environmental structure and bacterial lifestyle. Elife, 8: e47612

Shanbehzadeh, Saeed, Marzieh Vahid Dastjerdi, Akbar Hassanzadeh, and Toba Kiyanizadeh (2014) Heavy metals in water and sediment: a case study of Tembi River. J Environ Public Health

Sherene T (2010) Mobility and transport of heavy metals in polluted soil environment. In Biological Forum-An International Journal, 112-21

Singh J, Kalamdhad AS (2011) Effects of heavy metals on soil, plants, human health and aquatic life. Int J Res Chem Environ 1:15-21

Suami RB, Sivalingam P, Salah DMA, Grandjean D, Mulaji CK, Mpiana PT, Breider F, Otamonga J-P, Poté J (2020) Heavy metals and persistent organic pollutants contamination in river, estuary, and marine sediments from Atlantic Coast of Democratic Republic of the Congo. Environ Sci Pollut Res 27:20000-20013

Team, RStudio (2016) RStudio: integrated development for $\mathrm{R}$ version 1.0. 136, Boston: RStudio Inc
Tripathi V, Cytryn E (2017) Impact of anthropogenic activities on the dissemination of antibiotic resistance across ecological boundaries. Essays Biochem 61(1):11-21

Tripathi V, Tripathi P (2017). Antibiotic resistance genes: an emerging environmental pollutant. Perspectives in Environmental Toxicology. K. K. Kesari. Cham, Springer International Publishing: $183-201$

Xu J, Xu Y, Wang H, Guo C, Qiu H, He Y, Zhang Y, Li X, Meng W (2015) Occurrence of antibiotics and antibiotic resistance genes in a sewage treatment plant and its effluent-receiving river. Chemosphere 119:1379-1385

Zhang Y, Gu AZ, Cen T, Li X, He M, Li D, Chen J (2018) Sub-inhibitory concentrations of heavy metals facilitate the horizontal transfer of plasmid-mediated antibiotic resistance genes in water environment. Environ Pollut 237:74-82

Publisher's Note Springer Nature remains neutral with regard to jurisdictional claims in published maps and institutional affiliations. 